February 2022

\title{
What factors affect entrepreneurial intention in sharing accommodations? The application of the entrepreneurial event model
}

Jaewook Kim

University of Houston, jkim65@uh.edu

Liang(Rebecca) Tang

lowa State University, rebeccat@iastate.edu

\section{Xi Wang}

BNU-HKBU United International College, xiwang@uic.edu.cn

Follow this and additional works at: https://digitalcommons.usf.edu/jght

\section{in next page for additional authors \\ Part of the Entrepreneurial and Small Business Operations Commons, and the Hospitality}

\section{Administration and Management Commons}

This Refereed Article is brought to you for free and open access by the M3 Center at the University of South Florida Sarasota-Manatee at Digital Commons @ University of South Florida. It has been accepted for inclusion in Journal of Global Hospitality and Tourism by an authorized editor of Digital Commons @ University of South Florida. For more information, please contact digitalcommons@usf.edu.

\section{Recommended Citation}

Kim, J., Tang, L., Wang, X., \& Zhang, L. (2022). What factors affect entrepreneurial intention in sharing accommodations? The application of the entrepreneurial event model. Journal of Global Hospitality and Tourism, 1(1), 31-50. https://www.doi.org/10.5038/2771-5957.1.1.1002

\section{Corresponding Author}

Liang(Rebecca) Tang, 12 Mackay Hall, 2302 Osborn Dr., Dept. of Apparel, Events, \& Hospitality Management, lowa State University, Ames, IA, U.S. 50011-1078

Revisions

Submission: Apr. 18, 2021; 1st Revision: Sep. 2, 2021; Accepted: Oct. 20, 2021 
What factors affect entrepreneurial intention in sharing accommodations? The application of the entrepreneurial event model

\section{Authors}

Jaewook Kim, Liang(Rebecca) Tang, Xi Wang, and Linan Zhang 


\title{
What Factors Affect Entrepreneurial Intention in Sharing Accommodations? The Application of the Entrepreneurial Event Model
}

\author{
Conrad N. Hilton College of Hotel and Restaurant Management \\ University of Houston, USA \\ 1jkim65@uh.edu \\ College of Human Sciences \\ Iowa State University, USA \\ ${ }^{2}$ rebeccat@iastate.edu \\ ${ }^{4}$ linanz@iastate.edu \\ Division of Culture and Creativity \\ BNU-HKBU United International College, China \\ 33xiwang@uic.edu.cn
}

Jaewook Kim ${ }^{1}$, Liang (Rebecca) Tang ${ }^{2}$, Xi Wang ${ }^{3}$ and Linan Zhang ${ }^{4}$

\begin{abstract}
Hosts of sharing accommodation platforms are considered an evolving mode of entrepreneurs. This study aimed to examine the relationship among entrepreneurship capital (EC), perceived feasibility (PF), perceived desirability (PD), and entrepreneurial intention (EI) in sharing lodging by using the entrepreneurial event (SEE) model. Particularly, EC was evaluated as a second-order factor with four first-order sub-variables: financial, social, intellectual, and human capital (HC). Data were collected from online surveys completed by 328 respondents. Second-order factor analysis and structural equation modeling were used in the analysis. Results confirmed that all four sub-variables contributed to inclusive capital. Inclusive capital positively influenced PF and PD, which led to EI. This study contributes to the evolving knowledge of sharing accommodations and enriches the research body of entrepreneurship via examining hosts of sharing lodging as innovative micro-entrepreneurs. It offers practical tools to help prospective hosts assess whether they are ready to operate a sharing lodging business.
\end{abstract}

Keywords: entrepreneurship capital, entrepreneurial intention, perceived desirability, perceived feasibility, sharing accommodations

\section{Introduction}

The sharing economy, also called peer-to-peer (P2P) economy or collaborative consumption, has been one of the fastest-growing business trends since a decade ago (Geissinger et al., 2019). The sharing economy facilitates the exchange process of goods or services between two or more parties using technology (Netter et al., 2019). As a prevailing player in the sharing economy, sharing lodging is a phenomenon in which real estate property owners rent their extra space to others for a short period (Mao \& Lyu, 2017). Sharing accommodations has ushered in a new era of the accommodation sector and is expected to reshape the future of the entire hospitality industry 
(Chung, 2017). For example, as a pioneer of collaborative consumption platforms, Airbnb has more than 150 million users covering more than 65,000 cities across 191 countries (MuchNeeded, 2020). Except for Marriott (US\$29.65 billion), Airbnb's valuation (US\$29.21 billion) in 2020 exceeded the market capitalization of nearly all the major traditional lodging corporations, including Hilton (US\$20.7 billion) and Host (US\$12.7 billion) (Saleem, 2020).

Academic research on the topic of sharing lodging has emerged sporadically since 2010 (e.g., Heo, et al., 2019; Tussyadiah, 2016). Existing studies are classified into three themes. The first theme assesses business performance along with economic and social effects (e.g., Agarwal et al., 2019), pricing mechanism (e.g., Chen \& Xie, 2017; Xie \& Mao, 2017), and perceptions of residents (e.g., Chung, 2017; Xu et al., 2019). The second theme focuses on marketing and customer behavior (e.g., Liang, Choi, \& Joppe, 2018; Tussyadiah, 2016). The third theme discusses competition, coexistence, and relevant regulations and laws between hotels and sharing lodging listings (e.g., Heo et al., 2019; Williams \& Horodnic, 2017). However, sporadic studies have been found on the topic of entrepreneurship in sharing accommodations (ESA). Most of these studies were descriptive or only used entrepreneurs as an alternative term of hosts or without further investigations. The absence of entrepreneurship in business administration research for any specific economic form is similar to Shakespeare's work, in which "the Prince of Denmark has been expunged from the discussion of Hamlet" (Baumol, 1968, p. 66). Thus, the present study aims to fill the research gap.

Entrepreneurship describes a businessman's purposeful actions to originate, maintain, and grow a venture (Gries \& Naude, 2011). Entrepreneurship is a crucial mechanism for the development of an industry because it offers venues to increase economic development, create jobs, and promote social changes (Herron \& Robinson, 1993). Particularly, ESA as an evolving economic form show distinctions from traditional entrepreneurship. ESA offers anyone who offers shared living space business opportunities and experiences extraordinary challenges in regulations and laws, culture, and politics (Albinsson \& Perera, 2018). Thus, Kim et al. (2020) argued that entrepreneurship should be examined as a separate topic in the field of sharing accommodations. Entrepreneurship has been introduced into the sharing lodging literature only at the introductory conceptual level. Additional studies should be conducted to explore new but important research venues further. Krueger et al. (2000, p. 413) indicated "Entrepreneurial activity is intentionally planned behavior. Witness the tremendous emphasis on the business plan in virtually every academic and practical treatment on starting a new business." Thus, the entrepreneurship of sharing accommodations could be viewed as mass entrepreneurship among the general public (Matofska, 2016).

Motivating the general public to share extra living space is different from inspiring business persons to start a venture in traditional entrepreneurship (Kim et al., 2020). Therefore, understanding the formation of a host's entrepreneurial intention (EI) is a foundational phase in advancing knowledge regarding entrepreneurship in an innovative economy. Shapero's (1982) model of the entrepreneurial event (SEE) is an intention model explicitly designed for the entrepreneurship domain. In SEE, individuals' conation to initiate a new venture is derived from their perceptions of desirability and feasibility. Perceived desirability (PD) depicts how establishing a new venture is intrinsically and extrinsically attractive to individuals. In contrast, perceived feasibility (PF) explains how individuals feel capable of initiating a new venture (Guerrero et al., 2008). Therefore, the present study examined how PD and PF influence a host's EI. 
Alvarez and Busenitz (2001) suggested that various beliefs and values relevant to resources significantly influence entrepreneurs' perception of business opportunities and assist them in evaluating their capability to utilize these opportunities. Accordingly, individuals' perceptions of desirability and feasibility are affected by their resources to initiate a new venture, called entrepreneurship capital (EC) (Shane \& Venkataraman, 2000). EC is viewed as "the generated value of generated future entrepreneurial behavior" (Erikson, 2002, p. 277) or "a multiplicative function of competence and commitment" (Erikson, 2002, p. 278). Thus, EC was examined as the antecedent of PD and PF. Considering EC's unique business model, EC in sharing accommodations is differentiated from that in traditional ventures (Kim et al., 2020). Accordingly, Kim et al. (2020) defined four dimensions and their corresponding measures specific to EC for sharing accommodations, including intellectual, financial, social, and human capital. This multidimensional measurement was adopted in the present study.

This study tests the relationship among EC, PF, PD, and EI in sharing accommodations. The specific objectives of this work were as follows: 1) to reaffirm how overall capital is presented with four sub-variables (financial, social, intellectual, and human capitals), 2) to examine the influences of overall capital on PF and PD, and 3) to assess the effects of PF and PD on EI. The results of our study contribute to academia and industry. This study is a pioneer in the new research venue of ESA. Our results can assist micro-entrepreneurs in systematically assessing their resources and making wise decisions on whether to initiate sharing lodging businesses.

\section{Literature Review}

\section{Entrepreneurship in Sharing Accommodations (ESA)}

Entrepreneurship has been generally defined as the formation of a new enterprise (Vesper, 1984). It has been explained from different perspectives and emphases. In particular, goals (i.e., profitseeking) and actions (i.e., innovativeness) are two core components of the entrepreneurship definition that many scholars have agreed upon (e.g., Eisenhardt et al., 2000; Hisrich \& Sheperd, 2005; Manish \& Sutter, 2016). Studies of ESA are sporadic. Most of them just used microentrepreneurs as an alternative term of hosts without further discussions. For example, although hosts were termed as micro-entrepreneurs, Starbrowski (2017) focused on examining sharing lodging platforms as re-working social relations upon an innovative assemble of resources. As a descriptive study, Fischer et al. (2019) addressed the importance of technology-driven and knowledge-intensive entrepreneurship for hosts to become competitive in the sharing lodging market. Henama (2018) conducted a case study of Airbnb in South African and described the benefits of serving as hosts of sharing accommodations to individuals, communities, and the travel destination as a whole.

Studies that examined ESA as an emerging phenomenon and differentiated it from traditional entrepreneurship forms are limited. For example, Alrawadieh and Alrawadieh (2018) conducted a case study in Jordan and discussed the motivations, success factors, and challenges of ESA. Fischer et al. (2019) examined four motivational factors (i.e., pains, people, psychology, and profit) of hosts as micro-entrepreneurs of sharing accommodations. To the authors' knowledge, Kim et al. (2020) was the only research that reviewed and compared the features of ESA with over 30 forms of traditional entrepreneurship and conceptualized ESA based on collective theories of marketing, psychology, and sociology. They defined ESA as "innovative activities on P2P platforms, which 
allow the general mass to share spare spaces with other individuals in short or long terms for the purpose of profit" (Kim et al., 2020, p. 2). This definition serves as the foundation of the present study.

\section{Entrepreneurship Capital (EC)}

Resources or capitals are essential for entrepreneurship following resource-based theory (RBT). EC can be defined as the "stocks of available factors that are owned or controlled by the firm" (Amit \& Schomemaker, 1993, p. 35). RBT depicts a business as a heterogeneous gathering of exclusive and hard-to-imitate capitals (Barney, 1991). To elucidate the idea further, Kim et al. (2020) identified four components of entrepreneurial capitals of sharing accommodations (ECSA) as follows.

Financial Capital (FC): FC describes the financial capability of a business to acquire intramural and extramural resources (Coleman, 2007). Intramural capital includes private financial resources, and extramural capital refers to debt that a business can and wants to request (Kim et al., 2006). In traditional businesses, FC is composed of investments, taxes, loans, and credits. FC allows the hosts of sharing accommodations to afford a mortgage, purchase lodging amenities, employ housekeepers, and claim tax benefits (Kim et al., 2020).

Social Capital (SC): SC describes a venture's social resources associated with the relationship of a group or community (Payne et al., 2011). Nahapiet and Ghoshal (1998) suggested that these intangible assets exhibit trust, interaction ties, and shared values among members, determining whether a current relationship can be maintained or not. SC in sharing accommodations is demonstrated as a host's connection with repeat guests, engagement with the local community, and cooperation with P2P platforms (Kim et al., 2020).

Intellectual Capital (IC): IC refers to the knowledge and abilities of the management team in a business (Mouritsen \& Larsen, 2005). It comprises four aspects: domain knowledge, formal knowledge, management experience, and intrinsic motivation and creativity. Domain knowledge describes a host's ability to understand competitors, customers, and suppliers; assess laws and policies; and foresee future trends (Montag-Smit \& Maertz Jr, 2017). Formal knowledge makes a host aware of the business environment. Management experience refers to a host's former incidences relevant to leadership and administrative positions (Puhakka, 2010). Intrinsic motivations and creativity depict a host's impulse to seek business opportunities and be novel in business models (Carsrud et al., 2017; Dimov, 2017).

Human Capital (HC): HC refers to the extent of skills and abilities gained mainly through formal education, training, and context-related experiences (Becker, 2009). Kim et al. (2020) suggested that education and training should address the features of sharing lodging hosts as mass entrepreneurship and allow the general public to access effortlessly information related to marketing opportunities, government laws and regulations, and local communities' support resources. Accessible and straightforward information can assist prospective hosts in realizing that sharing lodging is a business model that fits everyone rather than professionals only. Contextrelated experience explains an individual's previous experience as a host or a guest of sharing accommodations (Ugalde-Binda et al., 2014). 
The present authors collected 41 papers on the topic of EC. These papers could be classified into three streams shown in Table 1. The dominant stream, composed of 24 articles, investigated how a specific type of EC (e.g., economic capital) impacts business development or a region's economic growth. For example, Bahrami et al. (2016) summarized how IC affects company entrepreneurship because organizational entrepreneurship is necessary to promote employees' ability and increase revenue. Samila and Sorenson (2017) identified how capability at distinct levels of allocation of venture capital motivates the economic growth of metropolitan areas. Kwon et al. (2013) measured the relationship between entrepreneurship and SC on the micro (e.g., company) and macro (e.g., regions) layers. Martin et al. (2013) analyzed the outcome of entrepreneurship education and training based on human capital theory. Estrin et al. (2013) utilized social capital theory to discuss the relationship between social and commercial entrepreneurship with a sample of businesses in 47 countries. The secondary stream, composed of 10 studies, analyzed how EC as a multidimensional construct shapes economic performance. For instance, Cabrita et al. (2015) described the role of entrepreneurship in regional development and built a framework between EC and regional development by analyzing intellectual, human, structural, and SCs. Urbano and Aparicio (2016) summarized the contributions of different types of entrepreneurial capital (i.e., physical, knowledge, and SC) in economic growth.

The third stream, which covered seven papers, discussed ECs and the behavior of entrepreneurs and employees. Three out of seven studies in this stream described entrepreneurial capital components and entrepreneurial behaviors. For example, Hayton (2005) developed a framework of the relationship between capital components and entrepreneurial behaviors in high-technology new ventures. Leitão and Franco (2008) discovered small and middle-sized enterprises' performance by establishing a model regarding individuals' entrepreneurship capacity and entrepreneurial performance. The other four papers in this stream focused on ECs and intention in different contexts. Specifically, Liñán and Santos (2007) introduced an intention model to investigate how SC impacts the shaping of EIs among undergraduate students. Ali and Yousuf (2019) conducted a case study in Pakistan and discussed the impact of SC on EI in rural communities. Passaro et al. (2018) conducted explorative research to investigate the effect of an entrepreneurial education program on the generation of IC and EI. Chia and Liang (2016) investigated the EI of college students majoring in tourism management by summarizing their capital sources.

Compared with the first two streams, the research in the third stream was limited, and those in the context of sharing economy were even less. Ahsan (2020) utilized Uber as an example to discuss the relationship between sharing economy and inequality to confirm the effectiveness among ethics and entrepreneurship. Liang et al. (2018) explained how individuals develop their microbusinesses on the sharing platforms from the supply side. In the same vein, the present research further investigates ECs and intentions in the context of sharing accommodations. 
Table 1. Summary of Literature in Terms of Entrepreneurship Capitals

\begin{tabular}{|c|c|c|c|c|}
\hline Research Theme & Sample Study & Data Collection & Methodology & Summary of Topic \\
\hline $\begin{array}{l}\text { A Specific Type of } \\
\text { EC }\end{array}$ & $\begin{array}{l}\text { Audretsch (2007); Audretsch \& } \\
\text { Keilbach (2004); Bahrami et al. } \\
\text { (2016); Baker et al. (2011); Bublitz } \\
\text { et al. (2018); Cope et al. (2007); } \\
\text { Crupi et al. (2020); De Bettignies \& } \\
\text { Brander (2007); Dimov (2017); Doh } \\
\text { \& Zolnik (2011); Estrin et al. (2013); } \\
\text { Estrin et al. (2016); Gedajlovic et al. } \\
\text { (2013); Kwon et al. (2013); Light \& } \\
\text { Dana (2013); Martin et al. (2013); } \\
\text { Marvel et al.(2016); Orser et al. } \\
\text { (2006); Paoloni et al. (2020); Percoco } \\
\text { (2012); Samilam \& Sorenson (2017); } \\
\text { Secundo et al. (2016); Ulhøi (2005); } \\
\text { Unger et al. (2011); Zhao et al. } \\
\text { (2011) }\end{array}$ & $\begin{array}{l}\text { Survey (3); } \\
\text { interview (3); } \\
\text { secondary } \\
\text { datasets (14); } \\
\text { N/A (4) }\end{array}$ & $\begin{array}{l}\text { Meta-analysis } \\
\text { (2); regression } \\
\text { analysis (11); } \\
\text { qualitative study } \\
\text { (2); clustering } \\
\text { analysis (1); } \\
\text { thematic analysis } \\
\text { (1); structural } \\
\text { equation } \\
\text { modeling (1); } \\
\text { N/A (4); } \\
\text { descriptive } \\
\text { analysis (1); } \\
\text { MIT's Genoma } \\
\text { model (1) }\end{array}$ & $\begin{array}{l}\text { Applied theories to establish the linkage between a } \\
\text { specific capital (e.g., SC) and travel destination } \\
\text { development and business success; discussed } \\
\text { advantages and disadvantages of a specific } \\
\text { entrepreneurship capital; developed strategies of } \\
\text { applying the entrepreneurial capitals at micro } \\
\text { (employees, companies) and macro (society) } \\
\text { layers; discovered research agendas on } \\
\text { entrepreneurial capitals; utilized the SC index to } \\
\text { examine the relationship among a specific capital } \\
\text { (e.g., SC) and entrepreneurship; solved } \\
\text { contradiction from diverse results of previous } \\
\text { studies on the relationship between types of } \\
\text { entrepreneurs and EC }\end{array}$ \\
\hline $\begin{array}{l}\text { Multiple Types of EC } \\
\text { (e.g., HC, FC, and } \\
\text { SC) }\end{array}$ & $\begin{array}{l}\text { Audretsch \& Keilbach (2004); } \\
\text { Audretsch \& Keilbach (2007); } \\
\text { Batjargal (2007); Cabrita et al. } \\
\text { (2015); Cetindamar et al. (2012); } \\
\text { Fatoki (2011); Fuller \& Tian (2006); } \\
\text { Pena (2002); Smith \& Stevens } \\
\text { (2010); Urbano \& Aparicio (2016) }\end{array}$ & $\begin{array}{l}\text { Survey (3); } \\
\text { interview (2); } \\
\text { secondary datasets } \\
\text { (4); N/A (1) }\end{array}$ & $\begin{array}{l}\text { Regression } \\
\text { analysis (6); } \\
\text { descriptive } \\
\text { analysis (1); } \\
\text { textual analysis } \\
\text { (1); N/A (2) }\end{array}$ & $\begin{array}{l}\text { Investigated the interaction, extent, and } \\
\text { relationship between multiple EC (e.g., human and } \\
\text { SCs) on a company's performance and region's } \\
\text { development; examined hypothesis by analyzing a } \\
\text { region's capacity based on entrepreneurial capitals; } \\
\text { examined gender difference in multiple EC in a } \\
\text { developing country. }\end{array}$ \\
\hline $\begin{array}{l}\text { Entrepreneurial } \\
\text { Intention and } \\
\text { Behavior }\end{array}$ & $\begin{array}{l}\text { Ali \& Yousuf (2019); Chia \& Liang } \\
\text { (2016); Gao et al. (2020); Hayton } \\
\text { (2005); Leitão \& Franco (2008); } \\
\text { Liñán \& Santos (2007); Passaro et al. } \\
\text { (2018) }\end{array}$ & $\begin{array}{l}\text { Secondary data } \\
\text { (1); survey (6) }\end{array}$ & $\begin{array}{l}\text { Regression } \\
\text { analysis (6); } \\
\text { structural } \\
\text { equation } \\
\text { modeling (1) }\end{array}$ & $\begin{array}{l}\text { Utilized theoretical hypotheses to examine the } \\
\text { impact of entrepreneurial capital and EI at micro } \\
\text { (individual) and macro (government, society) } \\
\text { levels; analyzed how an education program } \\
\text { impacts EI and form IC; investigated how } \\
\text { creativity and SC impact EI; discovered the impact } \\
\text { of entrepreneurial capitals and entrepreneurial } \\
\text { behavior on variables at the organization level; } \\
\text { established the relationship between } \\
\text { entrepreneurship capacity and entrepreneurial } \\
\text { performance based on organizational capital (e.g., } \\
\text { entrepreneurial behavior, organizational culture) }\end{array}$ \\
\hline
\end{tabular}




\section{Shapero's Model of the Entrepreneurial Event (SEE)}

Intention describes an individual's state of mind relevant to attention, experiences, and actions toward a specific object or behavioral patterns (Bird, 1988). EI is further defined as the conscious mindset that precedes actions and directs attention toward the goal of starting a new business (Krueger, 2017). The generation of intention to initiate an entrepreneurial career is a critical move in the long-lasting process of running a new business (Kessler \& Frank, 2009). The theory of planned behavior (TPB) was initially used to explain the formation of EI with attitudes toward entrepreneurship, subjective norms, and behavioral control (Ajzen \& Fishbein, 1980). Following TPB, Shapero and Sokol (1982) proposed a framework for explaining the formation of SEEs by incorporating situational, social, and individual perspectives. Thereafter, SEE has been used as a foundation for many predictive models of EI (e.g., Krueger et al., 2000; Guerrero et al., 2008). The framework assumes that inertia results in an individual's behavior until something interrupts or displaces inertia. Displacement happens when decision-makers look for the best available opportunity from various alternatives (Katz, 1960). Their decision relies on the relative credibility of optional behavior. When establishing a new venture, individuals' EI is motivated by perceived venture credibility. Perceived venture credibility describes entrepreneurs' capability and commitment to a new business venture (Turcan \& Fraser, 2016). Venture credibility is composed of PD and PF.

Perceived Feasibility $(P F)$ : PF refers to the individuals' view relevant to their capacity to conduct a specific action. In the context of entrepreneurship, PF describes individuals' perception of feasible future states that affect their attitude toward creating a new venture (Shapero \& Sokol, 1982). PF emphasizes individuals' mindset or outlook toward their potential to initiate a venture as a form of competence (Krueger \& Brazeal, 1994). PF is consistent with the variable of behavioral control in Ajzen's (1987) TBD, which addresses individuals' assessment of their capability to operate a start-up successfully. Such an assessment can shape their attitude toward a future start-up (Krueger \& Brazeal, 1994; Krueger et al., 2000).

Perceived Desirability (PD): PD discusses the extent of attraction that individuals perceive toward a specific action. In the context of entrepreneurship, PD describes the extent to which individuals recognize the prospect of initiating an attractive venture and generates the desire to act (Krueger \& Brazeal, 1994; Shapero \& Sokol, 1982). PD functions as a motivational factor that transforms positive attitude into intention or action (Kuehn, 2008). PD is similar to the variables of attitude and subjective norm in Ajzen's (1987) TBD (Krueger et al., 2000), which address inherent motives. Individuals' social background can be affected by individuals' social background, including culture, family, friends, and experiences relevant to entrepreneurship. The SEE model focuses on different aspects of the cognitive-behavioral frameworks. Thus, it serves as the theoretical foundation of the extended EI model in this study. On the basis of the SEE model, the following hypotheses were proposed:

- H1. PF positively influences EI in sharing accommodations.

- H2. PD positively influences EI in sharing accommodations. 


\section{Relationship Among Entrepreneurship Capital (EC), Perceived Feasibility (PF), and Perceived Desirability (PD)}

The SEE model can be distinguished by individuals' overall evaluation of their capability, which is composed of PF and PD that means attractiveness of entrepreneurship to individuals' career development in the future. However, this model fails to incorporate any initial conditions of individuals, interpreting why generating these perceptions toward entrepreneurship is impossible for them.

Following the goal-directed instrumental action framework in the psychology field, individuals prefer to chase capital and resources actively to increase their benefits (Dickinson \& Balleine, 1994). In the preceding discussions about RBT and the definitions of EC, resource heterogeneity is crucial for the setting of entrepreneurship (Barney, 1991). Entrepreneurs should consider different types of resources and capitals to form the perceptions of potential benefits that they may gain from entrepreneurship activities (Stefanone et al., 2012). Similarly, Kim et al. (2020, p. 3) conceptualized ECSA as "micro-entrepreneurs' perceptions of diverse resources that they actually possess and/or deem for use in the setup and operation of sharing lodging businesses. These resources are expected to influence their capabilities of identifying and exploring business opportunities." Especially on the sharing economy platforms, initial capitals are critical influential factors when individuals decide whether to share their excessive resources. That is, individuals' $\mathrm{PF}$ and PD are determined by their belief in the valuations of capitals that they can utilize for the venture (Alvarez et al., 2006). Accordingly, the following hypotheses were proposed, and a conceptual model based on the four aforementioned hypotheses is illustrated in Figure 1.

- H3. EC positively influences PF in sharing accommodations.

- H4. EC positively influences PD in sharing accommodations.

Figure 1. Conceptual Model

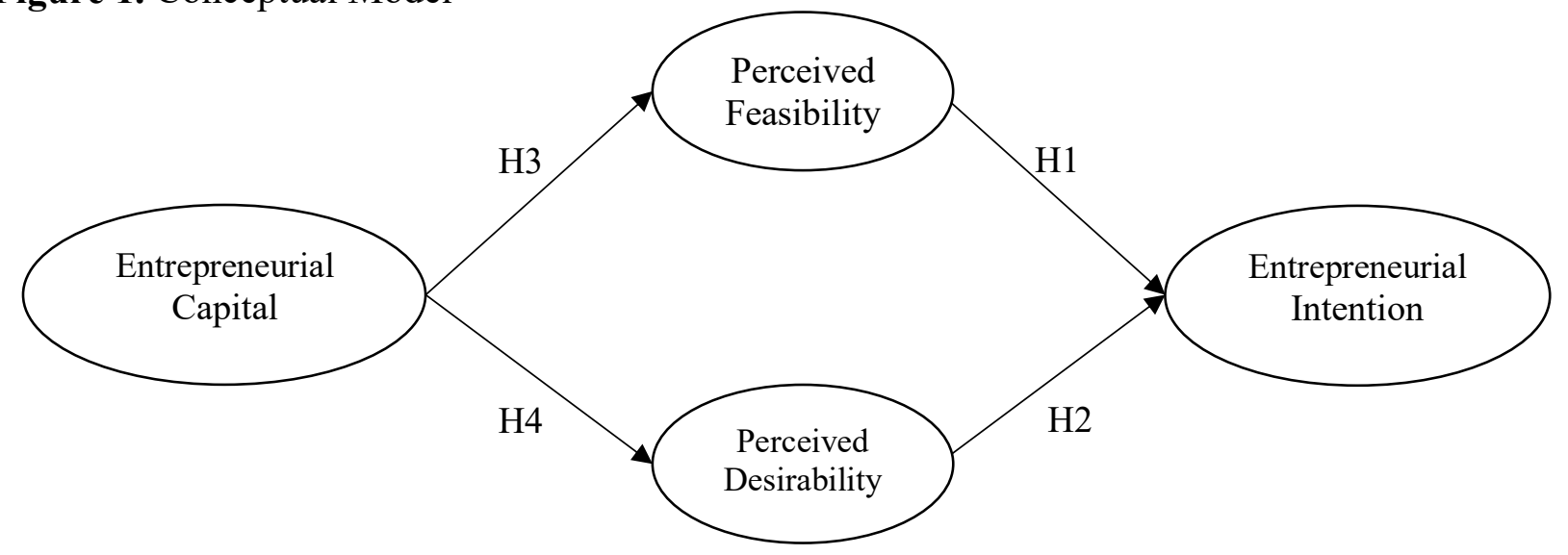

\section{Methods}

The purpose of the study was to conceptualize a holistic EI formation process, including ECs, feasibility, and desirability. Thus, by including these theory-driven variables linked to behavioral intention, cross-sectional analysis (i.e., CFA and SEM) was used to provide a fundamental understanding of how behavioral intention can be measured and what psychometric variables can potentially predict behavioral intention in the setting of sharing accommodations. A survey-based 
quantitative approach was employed to secure the generalizability of the holistic relationship drawn by the proposed model of EI formation and fulfill the purpose of this study.

\section{Sampling and Data Collection}

A questionnaire was distributed to a prequalified panel provided by ResearchNow, a professional marketing organization. To meet the objective of generalizability, we adopted a stratified sampling approach by considering the demographic diversity of respondents (e.g., age, gender, education, and income). The validity and reliability of instruments were determined by thoroughly reviewing individual items by experts in the field of hospitality management and pilot testing the survey among 150 target respondents on November 21 and December 9, 2016. The instruments were finalized with minor grammar revision by the authors. The main survey was conducted on January 13-17, 2017. Among the 372 questionnaires distributed, 328 responses were collected (response rate $=91.9 \%$ ). Furthermore, 308 responses in usable format were kept for further analysis. The profiles of the respondents are provided in Table 2.

\section{Instruments}

At the beginning of the survey, a screening question was asked about whether a respondent was aware of being a host on Airbnb as a micro-entrepreneurial opportunity. The rest of the questionnaire consisted of mainly two parts. The first part tested the construct of EC. EC was measured from four perspectives: SC, FC, IC, and HC. The scales of EC were obtained from Kim et al. (2020). The second part covered the measures of PF and PD. Four items were used for each of the two constructs originating from Liñán and Santos (2007) and Seligman (1991). The third part examined EI with four items adapted from Liñán and Santos (2007). All the items in the first three parts were measured using a scale of 1-7. The details of the items are provided in Table 3. The last part collected demographic information, including gender, age, racial background, education level, income, and employment status.

Common method variance (CMV) refers to the variance attributable to the measurement method as systematic error variance rather than to the construct of interest (Doty \& Glick, 1998). CMV was minimized by including common method factor in CFA and SEM as a statistical remedy. Furthermore, CMV arises from response tendencies that raters apply across measures, similarities in item structure or wording that induce similar responses, and the proximity of items in an instrument (e.g., Podsakoff et al., 2003). Thus, temporal separation by introducing a time lag between the measurement and randomized question order was applied as a procedural remedy to the survey process (Tourangeau et al., 2000). 
Journal of Global Hospitality and Tourism, Vol. 1, Iss. 1 [2022], Art. 3, pp. 31- 50

Table 2. Summary of Respondent's Profiles

\begin{tabular}{|c|c|c|}
\hline Characteristic & Frequency & Percentage \\
\hline \multicolumn{3}{|l|}{ Gender } \\
\hline Male & 141 & 45.8 \\
\hline Female & 167 & 54.2 \\
\hline \multicolumn{3}{|l|}{ Age } \\
\hline $18-24$ & 24 & 7.8 \\
\hline $25-30$ & 46 & 14.9 \\
\hline $31-40$ & 67 & 21.8 \\
\hline $41-50$ & 47 & 15.3 \\
\hline $51-60$ & 57 & 18.5 \\
\hline 61 or older & 67 & 21.8 \\
\hline \multicolumn{3}{|l|}{ Ethnicity } \\
\hline White & 244 & 79.2 \\
\hline Black or African American & 26 & 8.4 \\
\hline American Indian or Alaska Native & 5 & 1.6 \\
\hline Asian & 22 & 7.1 \\
\hline Native Hawaiian or Pacific Islander & 2 & 0.6 \\
\hline Other & 9 & 2.9 \\
\hline \multicolumn{3}{|l|}{ Education } \\
\hline Less than high school diploma & 1 & 0.3 \\
\hline High school diploma & 23 & 7.5 \\
\hline Some college & 181 & 59.0 \\
\hline Two-year degree & 21 & 6.8 \\
\hline Four-year degree & 41 & 13.4 \\
\hline Professional degree & 8 & 2.7 \\
\hline Doctorate & 32 & 10.4 \\
\hline \multicolumn{3}{|l|}{ Income Level } \\
\hline Less than $\$ 10,000$ & 29 & 9.4 \\
\hline$\$ 10,000$ to $\$ 19,999$ & 29 & 9.4 \\
\hline$\$ 20,000$ to $\$ 29,999$ & 37 & 12.1 \\
\hline$\$ 30,000$ to $\$ 39,999$ & 46 & 15.0 \\
\hline$\$ 40,000$ to $\$ 49,999$ & 31 & 10.1 \\
\hline$\$ 50,000$ to $\$ 59,999$ & 28 & 9.1 \\
\hline$\$ 60,000$ to $\$ 69,999$ & 15 & 4.9 \\
\hline$\$ 70,000$ to $\$ 79,999$ & 24 & 7.8 \\
\hline$\$ 80,000$ to $\$ 89,999$ & 17 & 5.5 \\
\hline$\$ 90,000$ to $\$ 99,999$ & 11 & 3.6 \\
\hline$\$ 100,000$ to $\$ 149,999$ & 27 & 8.8 \\
\hline Over $\$ 150,000$ & 13 & 4.2 \\
\hline \multicolumn{3}{|l|}{ Entrepreneurial Experience } \\
\hline Former entrepreneur but not now & 52 & 16.9 \\
\hline Prospective entrepreneur & 66 & 21.4 \\
\hline Currently active entrepreneur & 26 & 8.4 \\
\hline No entrepreneurial experience at all & 164 & 53.2 \\
\hline \multicolumn{3}{|l|}{ Employment Status } \\
\hline Employed full time & 129 & 41.9 \\
\hline Employed part time & 49 & 15.9 \\
\hline Unemployed looking for work & 21 & 6.8 \\
\hline Unemployed not looking for work & 24 & 7.8 \\
\hline Retired & 56 & 18.2 \\
\hline Student & 10 & 3.2 \\
\hline Disabled & 19 & 6.2 \\
\hline
\end{tabular}

Note. $N=308$ 
Table 3. Reliability and Convergent Validity

\begin{tabular}{|c|c|c|c|c|c|c|}
\hline Construct & $M$ & $S D$ & Cronbach's $\alpha$ & $\begin{array}{c}\text { Standardized } \\
\text { Factor Loadings }\end{array}$ & $\begin{array}{c}\text { Composite } \\
\text { Reliabilities }\end{array}$ & $A V E$ \\
\hline FC & & & .91 & & .88 & .60 \\
\hline $\mathrm{FC} 01$ & 5.08 & 1.60 & & .80 & & \\
\hline $\mathrm{FC} 02$ & 5.03 & 1.60 & & .83 & & \\
\hline $\mathrm{FC} 03$ & 4.95 & 1.51 & & .79 & & \\
\hline $\mathrm{FC} 04$ & 5.05 & 1.49 & & .79 & & \\
\hline $\mathrm{FC} 05$ & 4.71 & 1.63 & & .63 & & \\
\hline $\mathrm{SC}$ & & & .92 & & .89 & .61 \\
\hline $\mathrm{SC} 01$ & 4.96 & 1.53 & & .69 & & \\
\hline $\mathrm{SC} 02$ & 4.84 & 1.51 & & .72 & & \\
\hline $\mathrm{SC} 03$ & 5.25 & 1.50 & & .80 & & \\
\hline $\mathrm{SC} 04$ & 5.52 & 1.60 & & .84 & & \\
\hline $\mathrm{SC} 05$ & 5.50 & 1.52 & & .85 & & \\
\hline IC & & & .91 & & .88 & .64 \\
\hline IC01 & 5.22 & 1.45 & & .79 & & \\
\hline IC02 & 5.30 & 1.52 & & .85 & & \\
\hline $\mathrm{IC} 03$ & 5.14 & 1.50 & & .83 & & \\
\hline IC04 & 5.09 & 1.48 & & .73 & & \\
\hline $\mathrm{HC}$ & & & .76 & & .87 & .70 \\
\hline $\mathrm{HC} 01$ & 4.59 & 1.60 & & .79 & & \\
\hline $\mathrm{HC} 02$ & 4.89 & 1.54 & & .95 & & \\
\hline $\mathrm{HCO} 3$ & 5.37 & 0.96 & & .75 & & \\
\hline PF & & & .81 & & .82 & .53 \\
\hline PF03 & 5.66 & 1.34 & & .75 & & \\
\hline PF05 & 5.11 & 1.45 & & .56 & & \\
\hline PF06 & 5.76 & 1.40 & & .79 & & \\
\hline PF07 & 5.85 & 1.35 & & .81 & & \\
\hline PD & & & .80 & & .81 & .53 \\
\hline PD01 & 4.74 & 1.50 & & .68 & & \\
\hline PD02 & 5.34 & 1.44 & & .75 & & \\
\hline PD03 & 5.63 & 1.36 & & .84 & & \\
\hline PD06 & 5.57 & 1.47 & & .61 & & \\
\hline EI & & & .95 & & .95 & .84 \\
\hline EI01 & 3.95 & 1.89 & & .86 & & \\
\hline EI02 & 4.18 & 1.88 & & .91 & & \\
\hline EI03 & 4.05 & 1.94 & & .95 & & \\
\hline EI04 & 4.15 & 2.05 & & .93 & & \\
\hline
\end{tabular}

Note. $\mathrm{FC}=$ Financial Capital, $\mathrm{SC}=$ Social Capital, $\mathrm{IC}=$ Intellectual Capital, $\mathrm{HC}=$ Human Capital, $\mathrm{PF}=$ Perceived Feasibility, $\mathrm{PD}=$ Perceived Desirability, EI = Entrepreneurial Intention, AVE = Average Variance Extracted

\section{Data Analysis}

The two-step approach suggested by Anderson and Gerbing (1988) was applied to test the hypotheses. The first step was to conduct confirmatory factor analysis to reduce measurement errors caused by a multidimensional construct with various indicators (Garson, 2010). It can determine whether items reflect the actual relationships calculated from the data (Schumacker \& Lomax, 2004). In the second step, structural equation modeling (SEM) was used to model constructs as latent variables that, in contrast with observable variables, are not directly observed but are instead inferred from other variables that are observed and directly measured (Byrne, 1998). 


\section{Results}

\section{Measurement Model}

The goodness-of-fit indexes indicated that the model fit the data reasonably well: $\chi^{2}(436)=$ 908.802, $p<.001, \chi^{2} / d f=2.084$, comparative fit index $(C F I)=.925$, Tucker-Lewis index $(T L I)$ $=.915$, and root mean square error of approximation $(R M S E A)=.063$ with $90 \%$ confidence interval $(C I)$ of .057-.068. As indicated in Table 3, Cronbach's $\alpha$ ranged from .76 to .95 , which was greater than the recommended level of .70 (Nunnally, 1978), indicating satisfactory internal consistency. The measures of each construct demonstrated convergent and discriminant validities.

Standardized factor loadings were investigated for convergent validity. The inspection of these loadings showed that nearly all the loadings were above the cutoff value of .70, except for FC05, PD06, and PF05. These three items were uniquely loaded onto one factor; thus, they were kept for further analysis (Stepchenkova et al., 2010). The average variance extracted from each construct was also higher than the squared correlation coefficients among the constructs (Table 4).

Table 4. Squared Correlations Matrix and AVE

\begin{tabular}{|c|c|c|c|c|c|c|c|}
\hline Measure & PD & EI & PF & $\mathrm{HC}$ & IC & SC & FC \\
\hline PD & 1 & & & & & & \\
\hline EI & .0625 & 1 & & & & & \\
\hline PF & .5184 & .0529 & 1 & & & & \\
\hline HC & .2304 & .0196 & .1936 & 1 & & & \\
\hline IC & .4761 & .0361 & .3969 & .4624 & 1 & & \\
\hline SC & .4096 & .0324 & .3481 & .4096 & .6561 & 1 & \\
\hline FC & .4489 & .0361 & .3844 & .4356 & .5625 & .6084 & 1 \\
\hline AVE & .526 & .835 & .534 & .69 & .64 & .61 & .59 \\
\hline
\end{tabular}

Note. $\mathrm{PD}=$ Perceived Desirability; EI = Entrepreneurial Intention; $\mathrm{PF}=$ Perceived Feasibility; HC = Human Capital; IC = Intellectual Capital; SC = Social Capital; FC = Financial Capital; AVE = Average Variance Extracted

\section{Structural Model}

The structural model is illustrated in Figure 2. The proposed structural model exhibited acceptable fit with the data: $\chi^{2}(369)=1023.499, p<0.05, \chi^{2} / d f=2.774, C F I=.919, T L I=.911$, and $R M S E A$ $=.076$ with $90 \%$ CI: $.070-.081$. CFI was over the recommended cutoff value of .90, and RMSEA was within the acceptable range. This model also presented a low normed chi-squared value $\left(\chi^{2 / d f}\right.$ $=2.773$ ), which was less than 3 (Kline, 1998).

The four hypotheses were supported. First, all the parameter estimates in this model were statistically significant. $\mathrm{PF}(\mathrm{H} 1: \beta=0.223, p<.01)$ and $\mathrm{PD}(\mathrm{H} 2: \beta=0.564, p<.01)$ significantly influenced EI $\left(R^{2}=.324\right)$. Second, the coefficients of the path from EC to PF (H3: $\beta=0.760, p$ $<.01)$ and the path from EC to PD (H4: $\beta=0.802, p<.01)$ were statistically significant. Therefore, EC significantly influenced PF $\left(R^{2}=.577\right)$ and $\mathrm{PD}\left(R^{2}=.643\right)$ in sharing accommodations. One unit change in EC caused a 0.760-unit standard deviation change in PF and a 0.802-unit change in PD. Furthermore, one unit change in PF led to a 0.223-unit standard deviation change in EI, and one unit change in PD led to a 0.564-unit standard deviation change in EI. 
Figure 2. Structural Model With Standardized Parameter Estimates

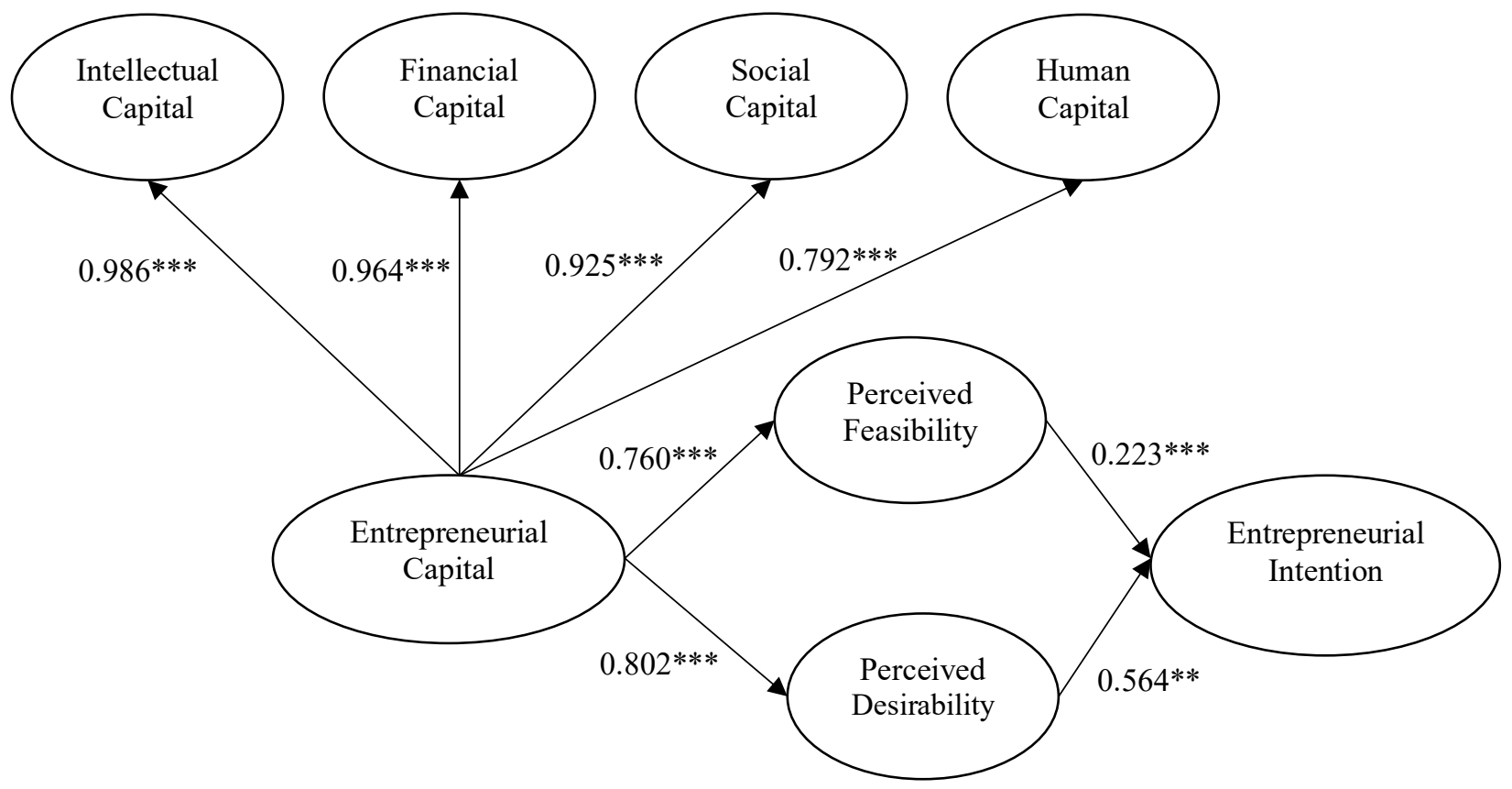

Note. ${ }^{*} p<0.05, * * * p<0.01, * * * p<0.001$

\section{Conclusions}

This study provides empirical evidence supporting the use of the universal scale of EC on the sharing accommodation platforms and the holistic model of EI formation based on RBT. The present research develops a holistic model that predicts individuals' EI in the extended model of EI formation on sharing accommodation platforms. Specifically, the TPB and SEE models are reflected with EC measures, which enable scholars to link individuals' beliefs on the value of their capital structure and its significance on the credibility of entrepreneurial venture that determines EI. The results confirm that EC is represented by four dimensions, including FC, SC, IC, and HC. EC positively influences PF and PD, resulting in EI. More detailed discussions are as follows.

First, a series of CFA was performed to identify the best fitting model of venture credibility by incorporating the PF and desirability of an entrepreneurial venture. Feasibility in this finding leaned toward the accountable outcomes from individuals' venture. Thus, feasibility can be understood as practical guidance toward a business venture given internal and external resources. Entrepreneurs in the sharing economy setting utilize and share their excessive resources (e.g., house on Airbnb, car on Uber, and tools on SnapGoods) in that the feasibility of entrepreneurial venture can significantly contribute to the overall perception toward entrepreneurship. Desirability, which focuses on individuals' perceived attractiveness of the business venture, explains the subjective norm and motivational factors. When prospective entrepreneurs only have limited resources, they need to assess whether investing in these resources to meet their desired outcomes is worthwhile.

Second, a holistic model of EI formation was developed. This model overarches three main variables, including EC, perceptions, and EI. This model proves that EC is positively associated with perceptions toward entrepreneurial venture by employing ECS on sharing economy platforms. 
This finding supports previous studies (e.g., Alvarez \& Barney, 2000; Shane \& Venkataraman, 2000), stating that RBT successfully fills the gap between EC and individuals' attitudes toward entrepreneurship. This attitude toward EC leads to the overall assessment regarding selfconfidence, attractiveness of being an entrepreneur, and willingness to start a venture on the sharing economy platforms. This perception is a significant determinant of EI. Individuals' comprehensive evaluation regarding their internal (social relationships, creativity, and motivation) and external (physical assets such as house, car, tools, and music) resources and motivational factors (feasibility and desirability) strengthen behavioral intention to exploit entrepreneurial opportunities.

\section{Theoretical Implications}

The present study has significant theoretical implications. First, sharing lodging is a relatively new topic in the hospitality discipline. Among the available limited research, Kim et al. (2020) was the only one that examined hosts' behavior as entrepreneurship. Similarly, we examined the consequential constructs of hosts' EC. Our study enriches the knowledge body of sharing accommodations from the entrepreneurship aspect. Second, to the authors' knowledge, the present study is the first to examine the PF and PD of ESA and even in the hospitality field. In particular, $\mathrm{PF}$ and PF make distinct contributions to EI.

Third, according to the summary in Table 1, the research themes of EC mainly consisted of three aspects, including a specific type of ECs (i.e., Audretsch, 2007), multiple types of ECs (i.e., Cabrita et al., 2015; Urbano \& Aparicio, 2016), and EI and behavior (i.e., Ali \& Yousuf, 2019; Chia \& Liang, 2016). However, the literature that examined EC from multiple perspectives is limited and even less in sharing accommodations. Our model investigates entrepreneurs' initial and crucial step for initiating sharing lodging businesses by examining the formation of EC through synthetically considering social, economic, political, and cultural perspectives based on psychology theories (i.e., TPB, SEE). It contributes to understanding the motives of the general public and further elaborates the research theme of entrepreneurial capital from multiple perspectives. The present study functions as a theoretical foundation for future empirical research related to the attitude and behavior of sharing lodging hosts. Our model also exhibits the potential

to be extended to other sharing economy platforms (e.g., urban transportation, crowdfunding, and co-working).

Fourth, given that the discussion of entrepreneurial capital was established based on the RBT, as mentioned in Section 2.2, the present study also contributes to RBT. Some previous studies in the hospitality and tourism field have applied RBT in diverse topics, such as resource allocation and optimization (e.g., Espino-Rodríguez \& Padrón-Robaina, 2005; Madanoglu \& Ozdemir, 2016). However, RBT's application in sharing lodging research has seldom been seen. Identifying four capitals (SC, FC, IC, and HC) can make a difference when potential sharing lodging businesses evaluate their ECs and go a step further to conduct RBT and other resource-based analyses in sharing accommodations and sharing economy in general.

\section{Practical Implications}

The present study also has significant practical implications. First, this study supported the opinion of Kim et al. (2020) that hosts of sharing accommodations are a new type of entrepreneurs, further proving the applicability of their 17-item ECSA scale. This study also provided a new venue for 
industry practitioners, government offices, and even the general public to understand and discuss sharing lodging as a relatively new economic phenomenon. Furthermore, the four sub-dimensions and their corresponding ECSA measures can be used as benchmarks for prospective hosts to selfassess whether they have the basic resources for becoming micro-entrepreneurs of sharing lodging businesses from personal, social, economic, political, and cultural perspectives.

Second, the results indicate that EC exerts positive effects on an individual's PF and PD of an entrepreneurial venture in a sharing lodging business. From the assessment results of the available capitals or resources, prospective hosts are advised to assess whether they are willing to operate a sharing lodging business and whether their business goal is achievable as two separate questions. Given the deficiency in professional knowledge and skills, the general public may not be confident in conducting such systematic marketing opportunity assessment, particularly the causality among capital, feasibility, and desirability. Thus, sharing lodging platforms are advised to offer free assessment toolkits to prospective hosts, allowing them to input the required information to obtain the evaluation results on whether they are materially and psychologically ready to operate a new business. Furthermore, sharing lodging platforms can offer personalized consulting services to prospective hosts. Consultants can adopt our model to assess the extent of competency and interest of prospective hosts precisely and accordingly help them make a wise decision on whether they should initiate a sharing lodging business.

Besides, referring to RBT, every organization makes strenuous efforts to develop its competitive advantage on resources (Joyce \& Winch, 2004). However, an organization often has to take the trade-off among kinds of resources (capitals). The results of this study provide industry practitioners in sharing lodging more strategies for evaluating capital. Through a systematic understanding of the four capitals ( $\mathrm{SC}, \mathrm{FC}, \mathrm{IC}$, and $\mathrm{HC}$ ), potential practitioners of sharing lodging business can constructively evaluate their capitals, avoid investment risk, and maximize business profit.

Fourth, sharing platforms and government offices are advised to educate the general public about entrepreneurship in the sharing lodging industry. Sharing lodging is an innovative business model for grassroots entrepreneurship, and it fits any individual who has adequate resources. Sharing spare spaces for a short period is undervalued by the general public as only a means to increase family income temporarily or cope with being unemployed. The general public should be made aware that operating a sharing lodging business is a form of entrepreneurship that can increase their sense of pride and responsibility. Education and training in different formats (e.g., workshops) on diverse platforms (e.g., social media) should reflect the findings of our study and emphasize the characteristics of the lodging industry; the unique value of entrepreneurship in the sharing economy; and resources, opportunities, and challenges in this novel marketplace. Furthermore, the sharing economy is an economic principle that is continually progressing. Entrepreneurs should update their knowledge from these educational resources about marketing, management, communication, accounting, and technologies.

\section{Limitations and Future Research}

This study bears several limitations. First, it collected data before the COVID-19 outbreak. The COVID-19 pandemic has put the travel industry at a standstill. Thus, sharing accommodations has faced unprecedented challenges because of the hygiene concerns of hosts and guests. Specifically, from hosts' perspectives, their capitals to cope with health risks (e.g., provision of extra hygiene 
measures) and PD and feasibility (re-evaluation of the profit/loss ratio due to the changes by the pandemic) may all change, influencing their EI. Therefore, the authors suggest future studies to re-test the model during and post the COVID-19 pandemic and even incorporate new variables (e.g., capital of hygiene measures) specifying the new normal into the model. Second, this study only tested EI as the consequential variable instead of actual behavior. A gap still exists between intent and action. Future studies are advised to test entrepreneurial behavior as the resultant construct of the model instead of intention. Furthermore, future studies could also use longitudinal, chronological case studies to identify micro-entrepreneurs' intention-behavior gap on sharing lodging platforms.

Third, our model was founded on SEE. The important antecedents of EI originating from other psychology theories can also be incorporated into models in future studies. Some examples include subjective norms and the subjects perception of behavioral control in TPB, attitude prediction and reactions in entrepreneurial attitude orientation, propensity to act in the potential entrepreneurial model, and conviction and domain attitude in the Davidsson model. Fourth, we did not collect the nationality information of the respondents, thereby disregarding the effect of culture. Sharing accommodations have become popular globally. Thus, future studies should compare the conceptual model results among prospective entrepreneurs in different countries, possibly gaining new insights for industry practitioners. Furthermore, other demographic and sociodemographic factors (e.g., income, age, and gender) can also be used as the moderators of the conceptual model in future studies. Lastly, our model was designed for the sharing lodging platforms. Future studies are advised to apply this model in other contexts of sharing economy to increase generalizability, including ride-sharing, co-working, and crowdfunding.

\section{References}

Agarwal, V., Koch, J. V., \& McNab, R. M. (2019). Differing views of lodging reality: Airdna, STR, and Airbnb. Cornell Hospitality Quarterly, 60(3), 193-199.

Ahsan, M. (2020). Entrepreneurship and ethics in the sharing economy: A critical perspective. Journal of Business Ethics, 161(1), 19-33.

Ajzen, I. (1987). Attitudes, traits, and actions: Dispositional prediction of behavior in personality and social psychology. Advances in Experimental Social Psychology, 20, 1-63.

Ajzen, I., \& Fishbein, M. (1980). Understanding attitudes and predicting social. Prentice-Hall.

Albinsson, P. A., \& Perera, B. Y. (2018). The rise of the sharing economy: Exploring the challenges and opportunities of collaborative consumption. ABC-CLIO.

Ali, A., \& Yousuf, S. (2019). Social capital and entrepreneurial intention: Empirical evidence from rural community of Pakistan. Journal of Global Entrepreneurship Research, 9(1), 1-13.

Alrawadieh, Z., \& Alrawadieh, Z. (2018). Exploring entrepreneurship in the sharing accommodation sector: Empirical evidence from a developing country. Tourism Management Perspectives, 28, 179-188.

Alvarez, R. D., DeNoble, A. F., \& Jung, D. (2006). Educational curricula and self-efficacy: Entrepreneurial orientation and new venture intentions among university students in Mexico. In C. S. Galbraith, \& C. H. Stiles (Eds.), Developmental entrepreneurship: Adversity, risk, and isolation (pp.379-403). Emerald.

Alvarez, S. A., \& Barney, J. B. (2000). Toward a creation theory of entrepreneurship. Fisher College of Business.

Alvarez, S. A., \& Busenitz, L. W. (2001). The entrepreneurship of resource-based theory. Journal of Management, 27(6), 755-775.

Amit, R., \& Schoemaker, P. J. (1993). Strategic assets and organizational rent. Strategic Management Journal, 14(1), 33-46.

Anderson, J. C., \& Gerbing, D. W. (1988). Structural equation modeling in practice: A review and recommended two-step approach. Psychological Bulletin, 103(3), 411.

Audretsch, D. B. (2007). Entrepreneurship capital and economic growth. Oxford Review of Economic Policy, 23(1), 63-78. 
Audretsch, D. B., \& Keilbach, M. (2004). Does entrepreneurship capital matter? Entrepreneurship Theory and Practice, 28(5), 419-430.

Audretsch, D. B., \& Keilbach, M. (2007). The localisation of entrepreneurship capital: Evidence from Germany. Papers in Regional Science, 86(3), 351-365.

Bahrami, P., Nosratabadi, S., \& Illés, C. B. (2016). Role of intellectual capital in corporate entrepreneurship. Calitatea, 17(155), 111.

Baker, E., Onyx, J., \& Edwards, M. (2011). Emergence, social capital and entrepreneurship: Understanding networks from the inside. Emergence: Complexity and Organization, 13(3), 21-38.

Barney, J. (1991). Firm resources and sustained competitive advantage. Journal of Management, 17(1), 99-120.

Batjargal, B. (2007). Internet entrepreneurship: Social capital, human capital, and performance of Internet ventures in China. Research Policy, 36(5), 605-618.

Baumol, W. J. (1968). Entrepreneurship in economic theory. The American Economic Review, 58(2), 64-71.

Becker, G. S. (2009). Human capital: A theoretical and empirical analysis, with special reference to education. University of Chicago.

Bird, B. (1988) Implementing entrepreneurial ideas: The case for intention. Academy of Management Review, 13(3), $442-453$.

Bublitz, E., Nielsen, K., Noseleit, F., \& Timmermans, B. (2018). Entrepreneurship, human capital, and labor demand: A story of signaling and matching. Industrial and Corporate Change, 27(2), 269-287.

Byrne, B. M. (1998). Structural equation modeling: Basic concepts, application, and programming. Lawrence Earlbaum Associates.

Cabrita, M. R., Cabrita, C., Matos, F., \& Dueñas, M. D. P. M. (2015). Entrepreneurship capital and regional development: A perspective based on intellectual capital. In R. Baptista, \& J. Leitão (Eds), Entrepreneurship, human capital, and regional development (pp. 15-28). Springer.

Carsrud, A., Brännback, M., Elfving, J., \& Brandt, K. (2017). Motivations: The entrepreneurial mind and behavior. In M. Brännback, \& A. L. Carsrud (Eds.), Revisiting the entrepreneurial mind (pp. 185-209). Springer.

Cetindamar, D., Gupta, V. K., Karadeniz, E. E., \& Egrican, N. (2012). What the numbers tell: The impact of human, family and financial capital on women and men's entry into entrepreneurship in Turkey. Entrepreneurship \& Regional Development, 24(1-2), 29-51.

Chen, Y., \& Xie, K. (2017). Consumer valuation of Airbnb listings: A hedonic pricing approach. International Journal of Contemporary Hospitality Management, 29(9), 2405-2424.

Chia, C. C., \& Liang, C. (2016). Influence of creativity and social capital on the entrepreneurial intention of tourism students. Journal of Entrepreneurship, Management and Innovation, 12(2), 151-168.

Chung, J. Y. (2017). Online friendships in a hospitality exchange network: A sharing economy perspective. International Journal of Contemporary Hospitality Management, 29(12), 3177-3190.

Coleman, S. (2007). The role of human and financial capital in the profitability and growth of women-owned small firms. Journal of Small Business Management, 45(3), 303-319.

Cope, J., Jack, S., \& Rose, M. B. (2007). Social capital and entrepreneurship: An introduction. International Small Business Journal, 25(3), 213-219.

Crupi, A., Cesaroni, F., \& Di Minin, A. (2020). Understanding the impact of intellectual capital on entrepreneurship: A literature review. Journal of Intellectual Capital. 22(3),528-559.

De Bettignies, J. E., \& Brander, J. A. (2007). Financing entrepreneurship: Bank finance versus venture capital. Journal of Business Venturing, 22(6), 808-832.

Dickinson, A., \& Balleine, B. (1994). Motivational control of goal-directed action. Animal Learning \& Behavior, 22(1), 1-18.

Dimov, D. (2017). Towards a qualitative understanding of human capital in entrepreneurship research. International Journal of Entrepreneurial Behavior \& Research, 23(2), 210-227.

Doh, S., \& Zolnik, E. J. (2011). Social capital and entrepreneurship: An exploratory analysis. African Journal of Business Management, 5(12), 4961-4975.

Doty, D. H., \& Glick, W. H. (1998). Common methods bias: Does common methods variance really bias results? Organizational Research Methods, 1(4), 374-406.

Eisenhardt, K., Brown, S., \& Neck, H. (2000). Competing on the entrepreneurial edge. In G. D. Meyer, \& K. A. Heppard (Eds.), Entrepreneurship as strategy: Competing on the entrepreneurial edge (pp. 49-62). Sage.

Erikson, T. (2002). Entrepreneurial capital: The emerging venture's most important asset and competitive advantage. Journal of Business Venturing, 17(3), 275-290.

Espino-Rodríguez, T. F., \& Padrón-Robaina, V. (2005). A resource-based view of outsourcing and its implications for organizational performance in the hotel sector. Tourism Management, 26(5), 707-721. 
Estrin, S., Mickiewicz, T., \& Stephan, U. (2013). Entrepreneurship, social capital, and institutions: Social and commercial entrepreneurship across nations. Entrepreneurship Theory and Practice, 37(3), 479-504.

Estrin, S., Mickiewicz, T., \& Stephan, U. (2016). Human capital in social and commercial entrepreneurship. Journal of Business Venturing, 31(4), 449-467.

Fatoki, O. O. (2011). The impact of human, social and financial capital on the performance of small and mediumsized enterprises (SMEs) in South Africa. Journal of Social Sciences, 29(3), 193-204.

Fischer, S. L., Pahus, H. S., \& Bager, A. (2019). What motivates people to become Airbnb hosts-do we know enough? An exploration of the literature. Research in Hospitality Management, 9(2), 83-88.

Fuller, T., \& Tian, Y. (2006). Social and symbolic capital and responsible entrepreneurship: An empirical investigation of SME narratives. Journal of Business Ethics, 67(3), 287-304.

Gao, Q., Xu, J., Tao, Z., Liu, L., \& Wu, C. (2020). Exploration and analysis on the psychological capital of entrepreneurship and the deviant innovation behavior of employees. Frontiers in Psychology, 11, 1-10.

Garson, D. (2010). Statnotes: Topics in multivariate analysis: Factor analysis. NC State University http://faculty.chass.ncsu.edu/garson/pa765/statnote.htm

Geissinger, A., Laurell, C., Öberg, C., \& Sandström, C. (2019). How sustainable is the sharing economy? On the sustainability connotations of sharing economy platforms. Journal of Cleaner Production, 206, 419-429.

Gries, T., \& Naude, W. (2011). Entrepreneurship and human development: A capability approach. Journal of Public Economics, 3(1), 216-224.

Guerrero, M., Rialp, J., \& Urbano, D. (2008). The impact of desirability and feasibility on entrepreneurial intentions: A structural equation model. International Entrepreneurship and Management Journal, 4(1), 35-50.

Hayton, J. C. (2005). Competing in the new economy: The effect of intellectual capital on corporate entrepreneurship in high-technology new ventures. $R \& D$ Management, 35(2), 137-155.

Henama, U. S. (2018). Disruptive entrepreneurship using Airbnb: The South African experience. African Journal of Hospitality, Tourism and Leisure, 7(1), 1-16.

Heo, C. Y., Blal, I., \& Choi, M. (2019). What is happening in Paris? Airbnb, hotels, and the Parisian market: A case study. Tourism Management, 70(2), 78-88.

Herron, R.B., \& Robinson, Jr. (1993). A structure model of the effect of entrepreneurial characteristics on venture performance. Journal of Business Venturing, 8(3), 281-294.

Hisrich, P., \& Sheperd, D. (2005). Definition of entrepreneur today. Extract from entrepreneurship. Springer.

Joyce, P., \& Winch, G. (2004). A framework for codifying business models and process models in e-Business design. In W. Currie (Ed.), Value creation from e-business models (pp. 35-64). Butterworth-Heinemann.

Katz, D. (1960). The functional approach to the study of attitudes. Public Opinion Quarterly, 24(2), 163-204.

Kessler, A., \& Frank, H. (2009). Nascent entrepreneurship in a longitudinal perspective: The impact of person, environment, resources and the founding process on the decision to start business activities. International Small Business Journal, 27(6), 720-742.

Kim, J., Tang, L. R., \& Wang, X. (2020). The uniqueness of entrepreneurship in the sharing accommodation sector: Developing a scale of entrepreneurial capital. International Journal of Hospitality Management, 84, 1-9.

Kim, P. H., Aldrich, H. E., \& Keister, L. A. (2006). Access (not) denied: The impact of financial, human, and cultural capital on entrepreneurial entry in the United States. Small Business Economics, 27(1), 5-22.

Kline, R.B. (1998). Principles and practice of structural equation modeling. Guilford.

Krueger Jr, N. F., \& Brazeal, D. V. (1994). Entrepreneurial potential and potential entrepreneurs. Entrepreneurship Theory and Practice, 18(3), 91-104.

Krueger Jr, N. F., Reilly, M. D., \& Carsrud, A. L. (2000). Competing models of entrepreneurial intentions. Journal of Business Venturing, 15(5-6), 411-432.

Krueger, N. F. (2017). Entrepreneurial intentions are dead: Long live entrepreneurial intentions. In M. Brännback, \& A. L. Carsrud (Eds.), Revisiting the entrepreneurial mind (pp. 13-34). Springer.

Kuehn, K. W. (2008) Entrepreneurial intentions research: Implications for entrepreneurship education. Journal of Entrepreneurship Education, 11, 87-98.

Kwon, S. W., Heflin, C., \& Ruef, M. (2013). Community social capital and entrepreneurship. American Sociological Review, 78(6), 980-1008.

Leitão, J., \& Franco, M. (2008). Individual entrepreneurship capacity and performance of SMEs. African Journal of Business Management, 5(15), 6350-6365.

Liang, L. J., Choi, H. C., \& Joppe, M. (2018). Exploring the relationship between satisfaction, trust and switching intention, repurchase intention in the context of Airbnb. International Journal of Hospitality Management, $69,41-48$. 
Liang, X., Jiang, J., \& Li, E. Y. (2018). IT-based entrepreneurship in sharing economy: The mediating role of value expectancy in micro-entrepreneur's passion and persistence. International Journal of Information Systems and Change Management, 10(4), 352-373.

Light, I., \& Dana, L. P. (2013). Boundaries of social capital in entrepreneurship. Entrepreneurship Theory and Practice, 37(3), 603-624.

Liñán, F., \& Santos, F. J. (2007). Does social capital affect entrepreneurial intentions? International Advances in Economic Research, 13(4), 443-453.

Madanoglu, M., \& Ozdemir, O. (2016). Is more better? The relationship between meeting space capacity and hotel operating performance. Tourism Management, 52, 74-81.

Manish, G. P., \& Sutter, D. (2016). Mastery versus profit as motivation for the entrepreneur: How crony policies shape business. Journal of Entrepreneurship and Public Policy, 5(1), 95-112.

Mao, Z., \& Lyu, J. (2017). Why travelers use Airbnb again? An integrative approach to understanding travelers' repurchase intention. International Journal of Contemporary Hospitality Management, 29(9), 2464-2482.

Martin, B. C., McNally, J. J., \& Kay, M. J. (2013). Examining the formation of human capital in entrepreneurship: A meta-analysis of entrepreneurship education outcomes. Journal of Business Venturing, 28(2), 211-224.

Marvel, M. R., Davis, J. L., \& Sproul, C. R. (2016). Human capital and entrepreneurship research: A critical review and future directions. Entrepreneurship Theory and Practice, 40(3), 599-626.

Matofska, B. (2016, March 14). What is the sharing economy? The People Who Share. https://www.thepeoplewhoshare.com/blog/what-sharing-economy

Montag-Smit, T., \& Maertz Jr, C. P. (2017). Searching outside the box in creative problem solving: The role of creative thinking skills and domain knowledge. Journal of Business Research, 81, 1-10.

Mouritsen, J., \& Larsen, H. T. (2005). The 2nd wave of knowledge management: The management control of knowledge resources through intellectual capital information. Management Accounting Research, 16(3), 371-394.

MuchNeeded. (2020, January 5). Airbnb by the numbers: Usage, demographics, and revenue growth. https://muchneeded.com/airbnb-statistics/

Nahapiet, J., \& Ghoshal, S. (1998). Social capital, intellectual capital, and the organizational advantage. The Academy of Management Review, 23(2), 242-266.

Netter, S., Pedersen, E. R. G., \& Lüdeke-Freund, F. (2019). Sharing economy revisited: Towards a new framework for understanding sharing models. Journal of Cleaner Production, 221, 224-233.

Nunnally, J. (1978). Psychometric methods. McGraw-Hill.

Orser, B. J., Riding, A. L., \& Manley, K. (2006). Women entrepreneurs and financial capital. Entrepreneurship Theory and Practice, 30(5), 643-665.

Passaro, R., Quinto, I., \& Thomas, A. (2018). The impact of higher education on entrepreneurial intention and human capital. Journal of Intellectual Capital, 19(1), 135-156.

Payne, G. T., Moore, C. B., Griffis, S. E., \& Autry, C. W. (2011). Multilevel challenges and opportunities in social capital research. Journal of Management, 37(2), 491-520.

Pena, I. (2002). Intellectual capital and business start-up success. Journal of Intellectual Capital. 3(2), 180-198.

Podsakoff, P. M., MacKenzie, S. B., Lee, J. Y., \& Podsakoff, N. P. (2003). Common method biases in behavioral research: A critical review of the literature and recommended remedies. Journal of Applied Psychology, $88(5), 879$.

Puhakka, V. (2010). Versatile and flexible use of intellectual capital in entrepreneurial opportunity discovery. Journal of Management Research, 2(1), 1-26.

Saleem, R. (2020, March 13). Airbnb may be able to pull off a successful 2020 IPO but only if priced at a sweet spot for investors. Wccftech. https://wccftech.com/airbnb-may-be-able-to-pull-off-a-successful-2020-ipo-butonly-if-priced-at-a-sweet-spot-for-investors/

Samila, S., \& Sorenson, O. (2017). Community and capital in entrepreneurship and economic growth. American Sociological Review, 82(4), 770-795.

Schumacker, R., \& Lomax, G. (2004). A beginner's guide to structural equation modeling. Psychology.

Secundo, G., Dumay, J., Schiuma, G., \& Passiante, G. (2016). Managing intellectual capital through a collective intelligence approach. Journal of Intellectual Capital, 17(2), 298-319.

Seligman, M. (1991). Learned optimism. A. A. Knopf.

Shane, S., \& Venkataraman, S. (2000). The promise of entrepreneurship as a field of research. Academy of Management Review, 25(1), 217-226.

Shapero, A., \& Sokol, L. (1982). The social dimensions of entrepreneurship. In C. Kent, D. Sexton, \& K. H. Vesper (Eds.), Encyclopedia of entrepreneurship (pp. 72-90). Englewood Cliffs. 
Smith, B. R., \& Stevens, C. E. (2010). Different types of social entrepreneurship: The role of geography and embeddedness on the measurement and scaling of social value. Entrepreneurship and Regional Development, 22(6), 575-598.

Stabrowski, F. (2017). 'People as businesses': Airbnb and urban micro-entrepreneurialism in New York City. Cambridge Journal of Regions, Economy and Society, 10(2), 327-347.

Stefanone, M. A., Kwon, K. H., \& Lackaff, D. (2012). Exploring the relationship between perceptions of social capital and enacted support online. Journal of Computer-Mediated Communication, 17(4), 451-466.

Stepchenkova, S., Tang, L., Jang, S. S., Kirilenko, A. P., \& Morrison, A. M. (2010). Benchmarking CVB website performance: Spatial and structural patterns. Tourism Management, 31(5), 611-620.

Tourangeau, R., Rips, L. J., \& Rasinski, K. (Eds.). (2000). The psychology of survey response. Cambridge University.

Turcan, R. V., \& Fraser, N. M. (2016). An ethnographic study of new venture and new sector legitimation: Evidence from Moldova. International Journal of Emerging Markets, 11(1), 72-88.

Tussyadiah, I. P. (2016). Factors of satisfaction and intention to use peer-to-peer accommodation. International Journal of Hospitality Management, 55(5), 70-80.

Ugalde-Binda, N., Balbastre-Benavent, F., Canet-Giner, M. T., \& Escribá-Carda, N. (2014). The role of intellectual capital and entrepreneurial characteristics as innovation drivers. Innovar, 24(53), 41-60.

Ulhøi, J. P. (2005). The social dimensions of entrepreneurship. Technovation, 25(8), 939-946.

Unger, J. M., Rauch, A., Frese, M., \& Rosenbusch, N. (2011). Human capital and entrepreneurial success: A metaanalytical review. Journal of Business Venturing, 26(3), 341-358.

Urbano, D., \& Aparicio, S. (2016). Entrepreneurship capital types and economic growth: International evidence. Technological Forecasting and Social Change, 102, 34-44.

Vesper, K. H. (1984). Entrepreneurship: A new direction, or just a new label? Division of Research, Harvard Business School.

Williams, C. C., \& Horodnic, I. A. (2017). Regulating the sharing economy to prevent the growth of the informal sector in the hospitality industry. International Journal of Contemporary Hospitality Management, 29(9), 2261-2278.

Xie, K., \& Mao, Z. (2017). The impacts of quality and quantity attributes of Airbnb hosts on listing performance. International Journal of Contemporary Hospitality Management, 29(9), 2240-2260.

Xu, Y. H., Pennington-Gray, L., \& Kim, J. (2019). The sharing economy: A geographically weighted regression approach to examine crime and the shared lodging sector. Journal of Travel Research, 58(7), 1193-1208.

Zhao, W., Ritchie, J. B., \& Echtner, C. M. (2011). Social capital and tourism entrepreneurship. Annals of Tourism Research, 38(4), 1570-1593. 